\title{
A model for redeveloping complex, highly contaminated sites - the Industri-plex Site in Woburn, Massachusetts
}

\author{
C. N. Brooks \\ Greenfield Environmental Trust Group, Inc. (GETG), \\ Resources for Responsible Site Management, Inc. (RRSM), \\ The Industri-plex Superfund Site Custodial Trust (U.S. Federal District \\ Court, District of Massachusetts), USA
}

\begin{abstract}
This paper will describe how one of the most contaminated waste sites in the United States was transformed into a productive commercial center to become an international model for brownfields reclamation.

The Industri-plex Federal Superfund Site in Woburn, Massachusetts, is the fifth most contaminated waste site in the country, according to the US Environmental Protection Agency (USEPA). More than a century of heavy industry left a legacy of contamination, including metals in the soil, sediment and groundwater, and piles of odor-producing animal hides. Woburn is the home of two federal superfund sites-Industri-plex and the notorious Wells G\&H Site, where contamination in two drinking water wells was blamed for a cancer cluster. After a highly publicized lawsuit and release of Jonathan Harr's best selling book, A Civil Action, local property values plummeted, community trust was shattered and Woburn became nationally stigmatized.

Today, however, this former industrial wasteland has been reborn and is now home to US Fortune 100 giants Raytheon Corporation, Marriott Hotels and Target, which occupy a 900,000 square foot high-end office park and hotel campus and a 200,000 square foot retail center. A state-of-the-art regional transportation center provides train, bus and carpool services to thousands of regional commuters. More than the 4,000 new jobs and millions in new taxes that have been created, Industri-plex is a source of new-found hope and pride.

This paper details the strategies that led to redevelopment success, including the unprecedented use of an independent, third-party redevelopment advocate and trustee, the "Industri-plex Custodial Trust," to catalyze and implement reuse.

Winner of the prestigious National Phoenix Award for excellence in brownfield redevelopment, Industri-plex offers an innovative model with broad application to many sites, especially those gridlocked by complex contamination, property issues and divergent stakeholder interests.

Keywords: superfund, stigma, risk, liability, community, USEPA, PRPs, remedy, institutional controls, Custodial Trust, trust, redevelopment.
\end{abstract}




\section{Introduction}

\subsection{Site history}

The Industri-plex Site ("Industri-plex") in Woburn, Massachusetts was one of the first properties to be placed on the USEPA Superfund National Priorities List ("NPL") of the $\pm 1,200$ most hazardous sites. Originally ranked number 3, today the 245-acre Industri-plex is the fifth most contaminated waste site in the US.

The City of Woburn, Massachusetts is situated approximately twelve miles north of Boston along the busiest interstate highway interchange in the state. Its strategic location along the Middlesex Canal, the Boston and Maine Railroad and the Aberjona River helped transform Woburn during the 1800s into the leather producing capital of the US and cradle of the American industrial revolution.

From 1853 to 1969 Industri-plex hosted pesticide, munitions and leatherrelated manufacturing, culminating in the production of glue from animal carcasses that were a by-product of the tanning industry. Tri-sected by the old Boston and Maine Railroad that once serviced industrial operations, today the Site abuts a major north-south interstate highway that was built just a decade before manufacturing ceased in the 1960s. The property was sold in 1969 to a real estate developer who began constructing roads and subdividing parcels for an industrial park. Then, in 1979, after the developer was found excavating and stockpiling buried wastes, significantly aggravating the existing contamination, government regulators brought site development to a halt.

\subsection{Site contamination and the USEPA-selected remedy}

A century of intensive industrial use left this 245 -acre tract with extensive contamination. The major contaminants included: arsenic, chromium and lead in the soils and sediments; benzene and toluene in the groundwater; and four large piles of odor-producing animal hides.

To prevent exposure to contaminants by dermal contact, ingestion or inhalation, USEPA selected a remedy that required construction of permeable caps and covers over a 110-acre area of the Site. The minimum USEPAapproved "Basic Soil Cover" is comprised of a geotextile membrane covered by a layer of clean, vegetated fill. While protective of public health, the Basic Soil Cover precludes use of the property for anything but limited pedestrian access. Therefore, USEPA also allowed "Alternate Covers," such as asphalt or crushed gravel, to permit industrial or commercial use of the covered areas. Also, portions of the Site were already being used for light industry because the bankrupt, recalcitrant developer was able to subdivide and sell a number of parcels before his development was stopped. Consequently, USEPA chose to treat all existing buildings, parking lots and paved areas as "Equivalent Covers or Caps," thus allowing them to remain in place.

USEPA required use of a gas collection and treatment system to capture the hydrogen sulfide gas from one of the Hide Piles that was still decomposing and an interim groundwater remedy to treat the benzene and toluene. 
The sheer volume of contaminated soils at Industri-plex (in excess of 100 metric tons for arsenic alone [1]) practically and economically precluded their removal and disposal off-site. Because the remedy entailed leaving the contamination on-Site, USEPA required a mechanism to ensure that the caps and covers would be maintained in perpetuity. Hence the remedy included "Institutional Controls" - enforceable land use restrictions that remain attached to the land in perpetuity. The final draft Institutional Controls take the form of a grant of easement and restriction to the USEPA to be recorded on title to all Site properties. They rely on deed restrictions, restrictive covenants and easements to restrict land use, and they are enforced by the USEPA to ensure long-term compliance. The risk-bask corrective action (RBCA) selected for the Site inherently restricted future use to commercial or industrial activities.

The agency recognized that metals from Industri-plex, particularly arsenic, were likely entering the groundwater and Aberjona River, although the final clean-up plan for Aberjona River was not issued until 2005.

\subsection{Industri-plex Clean-up Settlement (Consent Decree) and creation of the Custodial Trust}

In 1989 the USEPA reached agreement on the Site clean-up plan with twentytwo "potentially responsible parties" (or PRPs). The PRPs included current and former property owners, two large chemical companies that inherited the majority of liability for the cleanup, and the then-bankrupt real estate developer who had substantially aggravated the contamination. The clean-up agreement between USEPA and the PRPs was set forth in a 1989 federal district court decree. The so-called Industri-plex Consent Decree established two separate trusts - a Remedial Trust and a Custodial Trust. Representing the PRPs, the Remedial Trust was responsible for funding, designing, constructing and maintaining the Site remedy under USEPA oversight. Considering the PRPdeveloper's legacy of recalcitrance and insolvency, USEPA allowed the developer to contribute his property in exchange for relief from liability for the clean-up. Thus a Custodial Trust was created to take title to the bankrupt developer's property.

The Industri-plex Consent Decree assigned a pivotal role to the Custodial Trust in the redevelopment process, including responsibility for: (i) receiving, holding, managing and securing the insolvent developer's property; (ii) cooperating with the Remedial Trust and USEPA on Site remediation; and (iii) with the prior approval of USEPA and the two major PRPs, selling all salable land and distributing the sale proceeds to the three designated beneficiaries of the Custodial Trust - the City of Woburn, the Remedial Trust (PRPs) and the USEPA. The Trustee was able to take title to the Industri-plex property because USEPA agreed to protect the Custodial Trust from liability under superfund.

\subsection{A case of civil action}

The discovery of contamination at Industri-plex coincided with the detection of contaminants in two Woburn drinking water wells-Well $\mathrm{G}$ and Well $\mathrm{H}-$ 
located on the Aberjona River south of the Site. The contaminated water was blamed for a childhood leukemia cluster that struck 28 children. Some of the Woburn families whose children died of leukemia filed a $\$ 400$ million class action law suit against three companies believed responsible for the contamination. The widely publicized toxic tort trials stigmatized Woburn, depressed local property values, polarized the community and shattered Woburn's century-long relationship with industry. After the 1995 publication of Jonathan Harr's best seller, A Civil Action [1], which documents the litigation, and Hollywood's subsequent release of a major motion picture starring John Travolta, Woburn's stigma became a national phenomenon. Beyond the human tragedy, Woburn's trust in government and industry was destroyed.

\section{The redevelopment process and results}

\subsection{Community partnering on redevelopment and infrastructure}

\subsubsection{Building an alliance with the community}

In a climate fraught by mistrust and betrayal, the Custodial Trust pursued an alliance with the community. Clearly any reuse of the Site required community consent because land-use in the US is always governed at the local level. At Industri-plex the community's active participation was critical to overcoming the challenges posed by extensive contamination and a legacy of mistrust and market stigma. Working with local officials, the Custodial Trust undertook a series of environmental, land use and market studies to evaluate reuse options in light of the opportunities and constraints posed by the contamination and the remedy, existing and potential infrastructure, and other site characteristics. Soon local officials began to view the Site as an asset, rather than the liability it had come to represent.

\subsubsection{Infrastructure: where redevelopment begins}

Initial efforts focused on infrastructure, which is the foundation for any wellplanned development. At Industri-plex, the Custodial Trust sought to improve and leverage existing infrastructure, such as the abutting highway, existing rail line, and other attributes that made the Site attractive for use in the first place. In partnership with the City of Woburn, the Custodial Trust led complex negotiations with three state transportation agencies-the Massachusetts Port Authority, the Massachusetts Bay Transportation Authority and the Massachusetts Highway Department (collectively, the "Transportation Agencies")-which resulted in a series of public-private agreements, and ultimately, construction of three major transportation projects at the Site: (i) a new interstate highway interchange providing direct highway access to the Site; (ii) a state-of-the-art intermodal, regional transportation center (RTC) that offers commuter rail, airport shuttlebus, van pool and park-and-ride services for 2,500 cars; and (iii) new public roads to reach landlocked areas. Under these public-private agreements the Custodial Trust donated the land, financed the acquisition of non-Custodial Trust property, and funded final design of the 
interchange; in exchange, the Transportation Agencies funded and constructed these projects.

\subsubsection{Integrating re-use into the remedy and public-private agreements}

To take advantage of the railroad that trisected Industri-plex, the 30-acre RTC was sited atop the highly contaminated former manufacturing plant parcel that abutted the railroad. The Transportation Agencies funded a more intensive "Alternate Cover" (up to 4-1/2 times thicker than the Basic Soil Cover) to enable final construction of the Central Passenger Station, underground utility installation, and potential expansion to a 5,000-car facility without coming into contact with contaminants. The RTC "Alternate Cover" operates as the remedy.

Further integrating future use into the remedy, new public roads were also constructed as the Alternate Cover for contaminated soils. The Custodial Trust built "clean fill" corridors so that underground utilities could be installed and maintained in the future without coming into contact with contaminated soils.

All told, the Custodial Trust helped secure almost $\$ 50$ million in public capital for these infrastructure projects. That level of public investment not only created significant property value, it also sent a badly needed message to a riskadverse private sector still struggling with concerns about environmental liability and market stigma. The state Transportation Agencies' decision to purchase, develop and occupy some of the most contaminated areas of the Site made a compelling case for the efficacy and safety of redeveloping Industri-plex.

\subsubsection{Honoring the past and looking to the future}

Determined to close a painful chapter in Woburn's history, the Custodial Trust worked with the community, the state legislature and the Transportation Agencies to dedicate the RTC to Jimmy Anderson, one of the first Woburn children to die of leukemia. Jimmy was the son of Anne Anderson, whose personal testimony before a grid-locked US Congress was instrumental in securing passage of the superfund laws in the US. Today the Anderson RTC symbolizes Woburn's re-birth and a powerful reminder of its past.

\subsection{Marketing and selling contaminated property}

By the mid-1990s the remediation and infrastructure improvements were underway, freeing the Custodial Trust to begin the marketing and sale of its property. In collaboration with the City of Woburn, the Custodial Trust pursued a host of local zoning and permitting initiatives to facilitate the City's desired reuse and realize the highest and best use of the property for the benefit of its three beneficiaries. Then, capitalizing on the Site's emerging infrastructure and a regional market shortage for well-situated "box retail" sites, the Custodial Trust helped secure final development permits and sold an 18-acre parcel to Minnesota-based Dayton Hudson Corporation for a record sale price of $\$ 640,000$ per acre of buildable land. Dayton Hudson Corporation then constructed a 200,000 square-foot retail center anchored by Target Stores at the site.

The Custodial Trust subsequently sold two additional parcels for development of a 900,000 square-foot, high-end office park and hotel complex. Today, this 
brick and glass corporate campus is home to Raytheon Corporation, Marriott Hotels and several other companies. The remediated wetlands and Hide Piles, which look like grass-covered hills, provide scenic open space.

By the mid-1990s few superfund properties had ever been sold. The significant risk of being named a potentially responsible party under the "strict, joint and several" liability scheme of the US hazardous waste clean-up laws has had a chilling effect on the sale of most superfund property. Typically, the multi-million dollar, ever-escalating costs to clean-up a superfund sites far exceed the value that can be derived from the real estate. At Industri-plex the USEPA's original estimate for the clean-up was $\$ 13$ million; to date, the Remedial Trust has spent close to $\$ 90$ million. Even the dramatic increase in total Custodial Trust property value-from an initial assessed value of $\$ 1,000,000$ "as if clean" to actual sales of almost $\$ 17$ million "as is and with all faults"- does not approach the cost of the remedy.

The specter of such liability led all Custodial Trust buyers to insist upon (as a condition precedent to closing) receipt of a Prospective Purchaser Agreement (PPA) from USEPA for superfund liability protection. Under the PPAs, USEPA granted a "covenant not to sue" for existing contamination in exchange for the buyers' cooperation on the remedy, grant of access, and inauguration of and compliance with Institutional Controls. The liability relief afforded under the USEPA PPA program was critical to ensuring that innocent purchasers of this superfund property, as well as their tenants, lenders and successors-in-title, could avoid becoming responsible parties under Superfund.

\subsection{Redevelopment results}

The economic rewards and other public benefits resulting from the Industri-plex redevelopment far exceeded most stakeholder expectations. To date, the Custodial Trust has distributed sale proceeds of almost $\$ 17$ million to its three designated beneficiaries: the City of Woburn; the Remedial Trust; and the USEPA. Table 1 (developed by USEPA) summarizes the jobs and state and local taxes that have been created by this project. A study, commissioned by the City of Woburn, predicts that redevelopment of the Site and the resulting development of surrounding properties will create as many as 12,000 new jobs by 2010 .

Beyond the positive economic impacts, this redevelopment has created many other benefits for the community and the environment. The Anderson RTC public transit services have helped to bring the state of Massachusetts into compliance with the US Clean Air Act by eliminating the air emissions from up to 2,500 vehicles commuting to and from Boston. Additionally, by constructing the intensive RTC Alternative Cover (in lieu of the Basic Soil Cover), the Transportation Agencies' remedy is more permanent and protective.

Most important, however, is that Woburn, Massachusetts has been re-born. Once characterized by former six-term Mayor John Rabbitt as, "the albatross of the Woburn," Industri-plex is now the economic center of this community. According John Rabbitt's successor, Mayor Robert Dever, "The transformation of this 245-acre site has restored Woburn's pride, hope and economic future." 
Industri-plex is not about forgetting the past; rather, as evidenced by the Anderson RTC, it has helped write the next, good-news chapter in Woburn's history.

Table 1: $\quad$ Economic results of redevelopment (USEPA) [2].

\begin{tabular}{|c|c|}
\hline $\begin{array}{l}\text { Short } \\
\text { Term }\end{array}$ & $\begin{array}{l}\text { - Average of more than } 700 \text { short-term jobs per year for two } \\
\text { years of redevelopment, with estimated total annual } \\
\text { income of } \$ 23.6 \text { million }\end{array}$ \\
\hline $\begin{array}{l}\text { Long } \\
\text { Term }\end{array}$ & $\begin{array}{l}\text { - As many as } 4,300 \text { permanent jobs created by } \\
\text { redevelopment } \\
\text { - Approximately } \$ 147 \text { million in annual income associated } \\
\text { with permanent jobs, expected to result in almost } \$ 118 \\
\text { million in personal spending }\end{array}$ \\
\hline $\begin{array}{c}\text { Public } \\
\text { Revenue }\end{array}$ & $\begin{array}{l}\text { - More than } \$ 13 \text { million in State income and sales tax } \\
\text { associated with spending } \\
\text { - More than } \$ 1.5 \text { million in State retail sales taxes annually } \\
\text { - More than } \$ 4 \text { million in local annual real estate taxes }\end{array}$ \\
\hline $\begin{array}{l}\text { Property } \\
\text { Value }\end{array}$ & $\begin{array}{l}\text { - Roughly } \$ 4.6 \text { million potential increase in residential } \\
\text { property values within two miles of site }\end{array}$ \\
\hline
\end{tabular}

\section{Lessons learned}

\subsection{Community-based redevelopment}

Communities have the most to lose or gain from the remediation and redevelopment of hazardous waste sites within their borders. In Woburn, Massachusetts, where the burden of contamination, stigma and mistrust seemed insurmountable, the stakes were huge. Nevertheless, availing themselves of the technical expertise and other resources provided by the Custodial Trust, the community was empowered by a clear understanding of their options. Given the choice, community and civic leaders elected to participate and lead. The Custodial Trust's alliance with the community was critical to its efforts to secure state and federal support and funding for a major new infrastructure projects.

A study of superfund land-use and remedy-selection by the Washington, DCbased not-for-profit research organization, Resources for the Future (RFF), analyzed the Industri-plex Site prior to actual Site redevelopment. It observed that "The Custodial Trust...has actively courted the community, involving legislative representatives at the local, state, and federal levels, cultivating contacts with the media, hosting or participating in local events... and attending public meetings on Industri-plex and often playing a major role in presenting and explaining developments at Industri-plex to the public. By most accounts, it has quite effectively mobilized Woburn citizens interested in development at the site" [3]. In another report, RFF states that, "The Trust has taken the lead at Industri-plex on redevelopment and promoted the most successful recent public 
involvement. It has made the [Anderson] RTC possible, with its political activities and garnering of public support, including its successful work with the transportation agencies to gain approval in the state legislature for \$20 million in bond bills to build the RTC and the new I-93 interchange" [4].

From the Custodial Trust's perspective, its alliance with the City of Woburn and the community's ability and willingness to make the case for these vital improvements were critical to the project's success.

\subsection{Creating value for all Custodial Trust beneficiaries}

The Custodial Trust pursued a host of strategies that resulted in the creation of significant, previously non-existent value for all stakeholders, some of which are highlighted below:

\subsubsection{Integrating re-use in the remedy}

Integrating re-use into the final Site remedy, best exemplified by the Anderson RTC, not only created new stakeholder value, it also helped ensure that that the redevelopment would be safe. The Remedial Trust realized significant remediation cost savings due to the shifting of costs from the remedy to the redevelopment. Additionally, the State Transportation Agencies have relieved the PRPs of potential future liability for the long-term stewardship of some of the Site's most contaminated areas. Finally, the Anderson RTC helped create significant real estate value by answering prospective purchaser concerns about the efficacy of the remedy as well as the stigma of the property.

\subsubsection{Managing risk and minimizing liability}

For prospective purchasers, tenants and lenders of Custodial Trust property, the PPA was an essential tool for managing their risk and avoiding superfund liability. The PRPs, concerned that reuse of the Site could give rise to possible future superfund liability, needed assurance that the purchasers had the resources and capabilities to comply with Institutional Controls. Accordingly, the Custodial Trust sought sophisticated buyers with financial depth and wherewithal to address the PRPs' concerns-buyers such as Raytheon Corporation, Target Stores, Marriott Hotels, even the Transportation Agencies.

\subsubsection{Multi-stakeholder alignment and public-private partnerships}

The structure of the Custodial Trust helped to align the diverse public and private interests. Vested with the rights and obligations of a private landowner, the Trust has direct fiduciary responsibility to the three major stakeholders to any superfund site-the community, the PRPs and the government regulators. Pursuant to its mandate, the Custodial Trust crafted solutions that balanced and satisfied the diverse goals of its three beneficiaries: (i) Woburn's desire to improve public transportation, create new jobs and tax revenues and overcome the stigma of superfund; (ii) the Remedial Trust's objective of maximizing sale proceeds to help offset the clean-up costs while minimizing future liability; and (iii) the USEPA goal to remediate the Site, and then, to the extent feasible, allow reuse in a manner protective of public health and the environment. 
Once it had arrived at a reuse plan that was supported by its three beneficiaries, the Custodial Trust was positioned to seek and negotiate multiple public-private agreements that resulted in the ambitious infrastructure improvements at the Site. As explained by USEPA, "The Custodial Trust has worked extensively with federal, state, and local officials and the neighboring communities to promote the redevelopment of the Industri-Plex site and its surrounding areas. At the heart of this redevelopment project was the public and private partnership that generated broad support for improvements at the site" [2]. The public-private partnerships that resulted in $\sim \$ 50$ million in major publicly funded infrastructure were critical to creating significant real estate value and overcoming market fears about the stigma of the property.

\subsection{The role of an independent third party - the Custodial Trust}

According to Resources for the Future (RFF), "Probably the most important feature contributing to the successful reuse [of Industri-plex] has been the custodial trust. This legal entity... has been an effective and innovative force that has brought to the cleanup process the development interests of local government, state agencies, and the private sector" [5].

As custodian and landowner of more than half of the 245-acre Site, the Custodial Trust has effectively functioned as an independent advocate for Site redevelopment, able to work outside the traditional superfund enforcement process. RFF notes that, "In creating the custodial trust, the consent decree effectively severed liability from the trust's redevelopment activities. The removal of liability has allowed the trust the opportunity to create private/public partnerships to attract large-scale retail outlets to the site...and to encourage the public and their elected officials to discuss reuse options. Large-scale development, we now know, can take place at a heavily contaminated NPL [superfund] site" [5].

Severing the Custodial Trust from superfund liability has indeed been a crucial ingredient to the success of Industri-plex. But more important was the Trust's ability to forge innovative agreements and initiatives that aligned the interests of many diverse stakeholders. It is worth noting that the Custodial Trust is strictly prohibited from engaging in commercial activities. Also, rather than taking an equity interest in the property, the Trust is compensated by management fee, thus avoiding any real or perceived conflict in the potentially competing goals of Site remediation and redevelopment.

\section{Conclusions}

Large, multi-faceted, multi-party sites with complicated contamination issues are often referred to as "upside down" properties (i.e., properties where the value of the real estate is significantly less than the cost of the clean-up). These sites require value creation strategies - such as integrating future use into the remedy, managing risk, minimizing liability and aligning key stakeholder interests- to overcome the barriers to reuse. The creation of an independent, third-party 
entity, such as the Industri-plex Custodial Trust, is also a widely applicable and useful mechanism for redeveloping large sites with complex contamination issues, property gridlock, or diverse and competing interests that require multistakeholder alignment and community-based solutions.

In a letter in support of the Industri-plex nomination for the prestigious National Phoenix Award, the Reverend Bruce Young, former minister for the Woburn Trinity Episcopal Church, wrote, "The Industri-plex Site will stand as a beacon of hope and offer a blueprint of management excellence to those who look at brownfields and ask, 'How can we ever remediate this site? It is so large and complex.' The answer - the model is found at Industri-plex."

\section{References}

[1] Hemond, Harold F. "Movement and Distribution of Arsenic in the Aberjona Watershed," Environmental Health Perspectives, pp. 36, Volume 103, Supplement 1, February 1995.

[2] Harr, Jonathan, A Civil Action, Random House Books, New York, 1997.

[3] Industri-plex Site Case Study, Superfund Redevelopment Initiative (SRI), U.S. Environmental Protection Agency (USEPA), OSWER 9378.0-19FS, Office of Solid Waste and Emergency Response, Online. www.epa.gov/superfund/programs/recycle/success/casestud/iplexcsi.htm

[4] Wernstedt, K., Hersh, R., \& Probst, K, "Basing Superfund Cleanups on Future Land Uses: Promising Remedy or Dubious Nostrum?" Discussion Paper 98-03, Resources for the Future, Washington DC, pp. 19, Oct. 1997.

[5] Wernstedt, K. \& Probst, K, "Land Use and Remedy Selection: Experience from the Field-The Industri-plex Site," Discussion Paper 97-27, Resources for the Future, Washington, DC, July 1997.

[6] Hersh, R., Probst, K, Wernstedt, K., \& Mazurek, Jan, "Linking Land Use and Superfund Cleanups: Uncharted Territory," Resources for the Future, pp. 43, June 1997, Internet Edition Online. www.rff.org. 